\title{
Zooplankton of the St. Lucia Estuary during the current drought cycle: a comparison between open- and closed-mouth conditions
}

\author{
Nicola K. Carrasco ${ }^{1, *}$, Renzo Perissinotto ${ }^{1}$, Deena Pillay ${ }^{2}$ \\ ${ }^{1}$ School of Biological and Conservation Sciences, University of KwaZulu-Natal, Westville Campus, Durban 4000, \\ Private Bag X5 4001, South Africa \\ ${ }^{2}$ Marine Research Institute, Zoology Department, University of Cape Town, Rondebosch 7701, Private Bag X3, South Africa
}

\begin{abstract}
The St. Lucia Estuary is currently experiencing a drought-induced crisis, resulting in the system having been closed off from the sea for approximately 8 yr. This closure was interrupted by a brief open-mouth phase, induced by a unique combination of extreme climatic events. The primary aim of the present study was to compare zooplankton dynamics during open- and closed-mouth conditions. Sampling was undertaken during quarterly surveys from February 2006 to November 2008. During the closed-mouth phase, up to $70 \%$ of the lake bed was dry and salinities in the northern lakes often exceeded 90, making these areas largely uninhabitable for zooplankton. However, in the lower regions where drought effects were less harsh, zooplankton were characterized by high densities and biomass of typical estuarine taxa such as the copepods Pseudodiaptomus stuhlmanni, Acartia natalensis and the mysid Mesopodopsis africana. Of the 69 taxa recorded during the study period, only 27 were present during the closed-mouth phase. Under open-mouth conditions, previously excluded marine taxa (e.g. the prawn Penaeus indicus and fish larvae), once again re-entered the system, increasing its diversity significantly. A unique occurrence after mouth re-closure was the colonisation of the mouth area by swarms of the tunicate Oikopleura dioica $\left(>10^{3}\right.$ ind. $\left.\mathrm{m}^{-3}\right)$, while previously dominant zooplankton grazers virtually disappeared. These findings emphasize the complexity of the system and stress the need for further research into the potential impacts of environmental and climate changes on this key African estuarine lake.
\end{abstract}

KEY WORDS: Zooplankton · Drought $\cdot$ St. Lucia Estuary $\cdot$ Extreme events $\cdot$ Oikopleura dioica

\section{INTRODUCTION}

The St. Lucia Estuary, on the eastern seaboard of South Africa, is a system that experiences periodic isolation from the Indian Ocean. This normally occurs during periods of low or no river inflow. Under such conditions, a sand berm may form across the estuary mouth (Taylor 2006). Similar estuaries are present in a variety of regions worldwide, e.g. Australia (Roy et al. 2001), Brazil and Uruguay (Bonilla et al. 2005), India and Sri Lanka (Ranasinghe \& Pattiaratchi 2003) and the USA, particularly California and Texas and occasionally as far north as Long Island, New York (Gobler et al. 2005). Within South Africa, approximately $70 \%$ of the currently functional estuaries are of this nature, with most of them being specifically classified as temporarily open/closed estuaries (Whitfield 1992).

The St. Lucia Estuary forms part of the iSimangaliso (formerly Greater St. Lucia) Wetland Park. iSimangaliso is South Africa's first World Heritage Site and has been designated a Ramsar Wetland of international importance (Begg 1978, Cyrus \& Vivier 2006). It is the largest estuarine lake in Africa (Fielding et al. 1991, Cyrus \& Vivier 2006). Covering an area of $325 \mathrm{~km}^{2}$, it represents approximately $80 \%$ of KwaZulu-Natal's total estuarine area (Begg 1978). The lake system is 
governed by cyclical wet and dry periods, each lasting between 4 and 10 yr (Begg 1978). The St. Lucia Estuary is currently experiencing a drought cycle, with below average rainfall persisting since 2002. Prior to 1920, the Mfolozi River discharged into the St. Lucia Estuary and would buffer water loss during periods of drought, but in the 1930s a canal was excavated through the Mfolozi flats for agricultural purposes (Begg 1978, Whitfield \& Taylor 2009). The natural filtration system of the swamps was, therefore, destroyed and the 2 systems have since been artificially maintained separately in an attempt to avoid the perceived threat of siltation from the Mfolozi. This alteration of the system's catchment has further exacerbated the severity of the current drought cycle.

The present drought has led to a drastic reduction in water levels and concomitant salinity increases. A reversed salinity gradient has persisted, with the occurrence of hypersaline conditions in the northern regions of the lake. The hypersaline conditions (70 to 90) that developed in the North Lake between 1969 and 1971 as a direct result of a previous drought led to a number of extraordinary changes in some of the basic trophic relations. These involved mainly: (1) a bloom of dinoflagellates (Grindley \& Heydorn 1970); (2) the dominance of chironomid larvae and harpacticoid copepods in bentho-pelagic samples (Grindley 1982); (3) a population explosion of aerial spiders; and (4) the loss of most of the plankton present, leaving only few species with high salinity tolerance (Grindley 1981).

Breaching in temporarily open/closed estuaries usually occurs because of increased precipitation in the catchment and greater head pressure in the lower estuary, resulting in a break of the sandbar (Whitfield 1992). On the 3rd of March 2007, however, the St. Lucia Estuary breached from the seaward side due to the combined effects of Cyclone Gamede and a spring equinox. This resulted in exceptional wave energy development in the surf zone and the consequent breakage of the $\sim 100 \mathrm{~m}$ sand berm (R. H. Taylor pers. comm.). This breaching event allowed seawater to enter the estuary for the first time in approximately $5 \mathrm{yr}$ and was unique in that the estuary was still experiencing drought conditions in the region.

A range of studies have highlighted the importance of zooplankton as indicators of change in marine systems (e.g. Bonnet \& Frid 2004, Beaugrand 2005). Their rapid response to ecosystem perturbations (Kiørboe \& Nielsen 1994, Hays et al. 2005) is achieved through strong coupling between environmental change and plankton dynamics (Roemmich \& McGowan 1995). In temporarily open/closed estuaries, maximum zooplankton abundance and biomass is generally recorded during closed-mouth conditions (Whitfield 1980, Kibirige \& Perissinotto 2003, Kibirige et al. 2006), with communities usually dominated by a few euryhaline taxa (Froneman 2004). Breaching events lead to the loss of zooplankton and their food resources, leaving low densities and biomasses during open-mouth conditions. Species richness, on the other hand, is typically greater during open phases, due to recruitment of marine neritic species within the estuary (Froneman 2004). Increases or decreases in precipitation and runoff may create extreme events - floods or droughts, respectively - and are increasing in frequency worldwide (Gleick 2003, Mirza 2003). The effects of such events remain unknown for estuarine communities, and are probably crucial for naturally variable systems such as the St. Lucia Estuary. From a zooplankton perspective, no comprehensive survey has been conducted in the St. Lucia Estuary, aside from the relatively outdated work by Grindley $(1976,1982)$. The present study, therefore, aims to determine the responses of zooplankton to open- and closed-mouth conditions, in terms of community structure, abundance and biomass. This knowledge would contribute significantly to the synthesis of information on the key producers of the St. Lucia Estuary, enhancing understanding of the ecology of this system, especially in response to environmental fluctuations.

\section{MATERIALS AND METHODS}

Quarterly surveys were undertaken at 5 representative stations within the St. Lucia Estuary, from February 2006 to November 2008. These stations were: the Mouth, Esengeni, Catalina Bay, Charters Creek and Listers Point (Fig. 1). The study period covered 3 different hydrological phases: a closed phase (Feb 2006 to Feb 2007), an open phase (Mar 2007 to Aug 2007) and a re-closed period (Nov 2007 to Oct 2008). Zooplankton, phytoplankton and microphytobenthic samples together with physicochemical data were collected at each site during each sampling season.

Physicochemical variables. Physicochemical measurements were made with a YSI 6920 water quality logger, fitted with temperature $\left({ }^{\circ} \mathrm{C}\right)$, depth $(\mathrm{m})$, salinity, dissolved oxygen $\left(\mathrm{mg} \mathrm{l}^{-1}\right)$, $\mathrm{pH}$ and turbidity (Nephelometric Turbidity Units [NTUs]) probes. Where possible, measurements were made at both the surface and the bottom of the water column. In cases where the water level was $<10 \mathrm{~cm}$ deep, the probe was placed horizontally so that all the sensors were submerged.

Pelagic and benthic microalgae. Subsurface water samples were collected at each of the 5 stations during each sampling season. Near-bottom water samples were collected with a pop bottle at sites where water levels were deep enough. One $250 \mathrm{ml}$ subsample was filtered through a GF/F filter to determine the total 


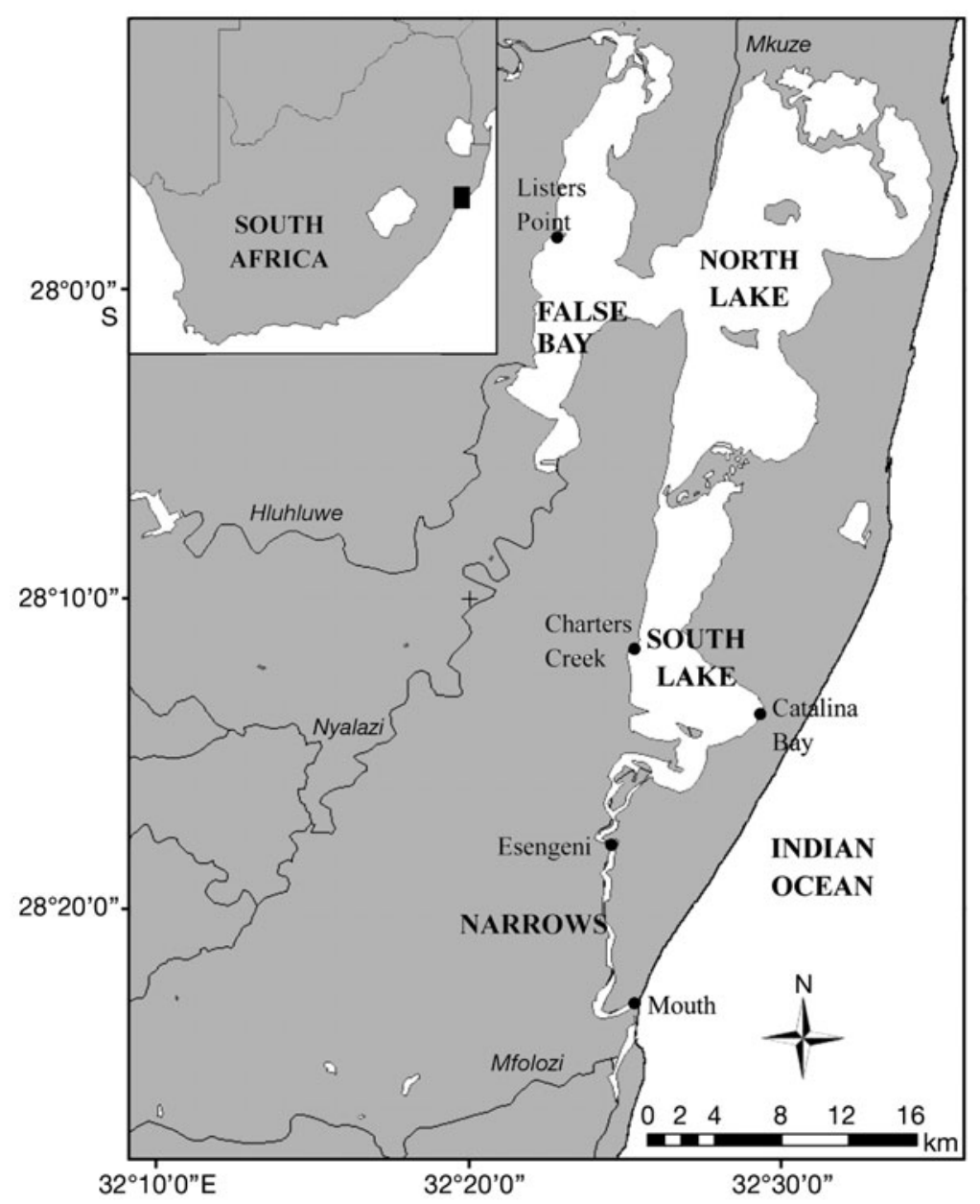

Fig. 1. St. Lucia Estuary, South Africa, and sampling sites mounted on a sled such that the net was raised $7.5 \mathrm{~cm}$ above the sediment surface. The volume of water filtered $\left(\approx 1.43 \mathrm{~m}^{3}\right)$ was calculated by multiplying the area of the sled mouth by the distance towed $(27 \mathrm{~m})$. The sample was emptied into a $500 \mathrm{ml}$ bottle containing $4 \%$ phloxine-stained formaldehyde. In regions where water depth was too shallow for the sled to be used, a hand held D-net (radius $=28 \mathrm{~cm}$ ) with the same mesh size was driven over a $20 \mathrm{~m}$ transect.

In the laboratory, samples were suspended in 0.5 to 51 solutions, depending on the density of organisms. The main sample was then stirred vigorously so that all the organisms remained in a homogenous suspension. A $20 \mathrm{ml}$ plastic vial attached to a metal rod was then used to withdraw 3 to 6 subsamples from mid-depth (Perissinotto \& Wooldridge 1989, Jerling \& Wooldridge 1995). Zooplankton within the samples were identified and counted with a dissecting microscope $(400 \times)$. In all cases, the coefficient of variation between subsamples was $<10 \%$. Zooplankton density was then calculated as ind. $\mathrm{m}^{-3}$.

Biomass was estimated as the total dry weight ( $\mathrm{mg} \mathrm{DW} \mathrm{m}^{-3}$ ) of the sample. The sample was divided into 2 equal portions with a Folsom plankton splitter (McEwen et al. 1954). Large detritus and sediment particles were removed from the sample under a dissecting microscope $(400 \times)$ and biomass was measured by oven drying half of each sample at $60^{\circ} \mathrm{C}$ for $24 \mathrm{~h}$. For those samples that contained too much detritus, between 10 and 50 ind. of each species were oven-dried $\left(24 \mathrm{~h}, 60^{\circ} \mathrm{C}\right)$ in pre-weighed tin capsules. Triplicate weights were recorded for each species. The average weight for each species was then multiplied by the respective abundance so as to obtain the average dry weight per sample.

Statistical analyses. Univariate statistical analyses were conducted with SPSS 15 for Windows. Data which did not satisfy the assumptions of parametric testing (i.e. normality and even distribution of residuals) were normalised using a $\log (x+1)$ transformation. Two-way ANOVA without replication (Zar 1996) was applied to test for possible spatial and temporal differences in total zooplankton abundance, biomass and diversity. Results from these tests showed no seasonal variation within each mouth state, allowing 1-way ANOVA with post hoc Tukey's tests to be used to test for differences (in phytoplankton and microphytobenthic biomass as well as zooplankton abundance, biomass and diversity) between stations and between mouth states. Spearman's rank correlations were used 
to test for relationships between environmental variables and the 3 univariate community parameters.

Multivariate analysis was conducted on abundance data using the PRIMER package (version 6.0). All data were square-root transformed. Analysis of similarity (ANOSIM) showed no significant seasonal difference in zooplankton community structure within each hydrological phase (closed, open and re-closure). For this reason, densities of taxa during each season were averaged to give the mean abundance of each taxon at the different stations during each of the mouth phases. A Bray-Curtis similarity matrix was then calculated from the 5 stations sampled during the different mouth phases. Cluster analysis (group averaged) and multidimensional scaling (MDS) were used to visually assess spatio-temporal differences in zooplankton assemblages, which were then tested using ANOSIM. Where differences were found, the similarity percentage (SIMPER) routine determined the relative contribution of individual species to community structure between mouth states. The BIOENV function (using harmonic Spearman correlation) was then used to relate environmental variables to the zooplankton communities.

\section{RESULTS}

\section{Physical environment}

During the closed-mouth phase, $>50 \%$ of the estuary was dry and the greatest water depth recorded was $2.48 \mathrm{~m}$ at the Mouth in April 2006. During the open-mouth phase, all sites were submerged or inundated and, while most northern lake stations were ini- tially very shallow, by the time the mouth re-closed in August 2007, water levels approached 2003 levels ( 0.9 $\mathrm{m}$ average).

During the closed phase, a reversed salinity gradient existed throughout the estuary (Table 1), ranging from
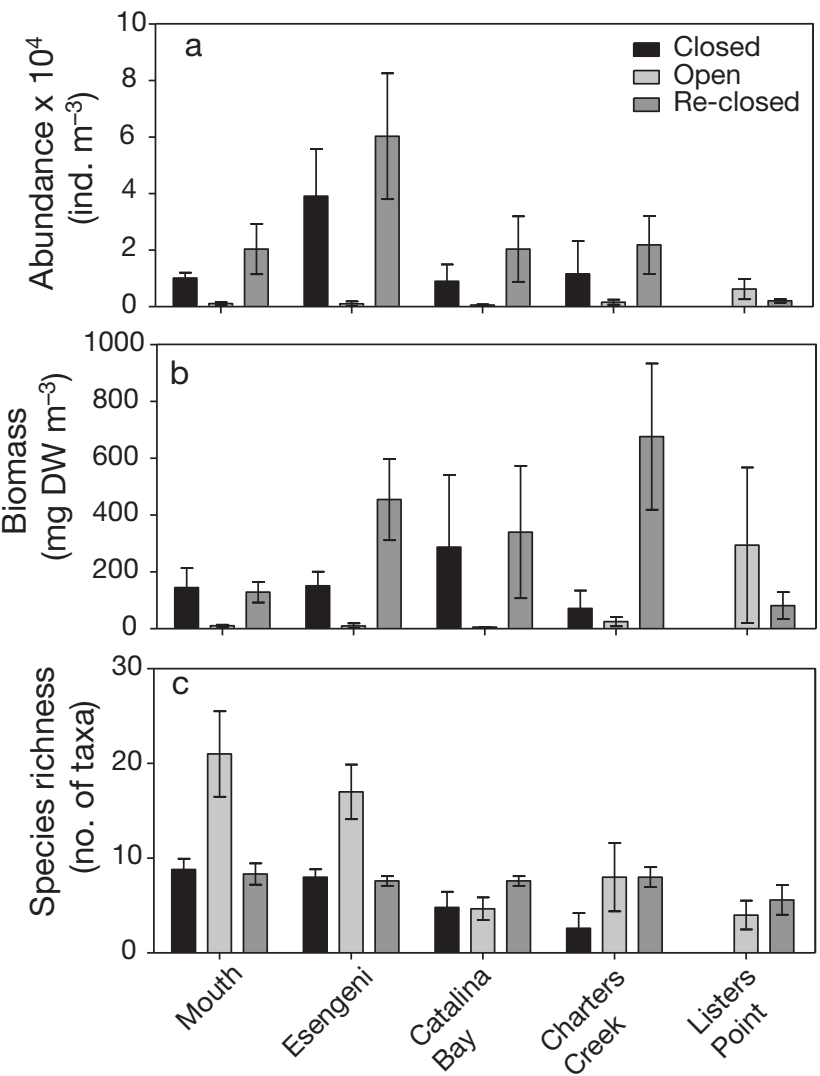

Fig. 2. Average $( \pm \mathrm{SE})\left(\right.$ a) total zooplankton abundance $\left(\times 10^{4}\right)$, (b) biomass and (c) species richness during the closed, open and re-closed mouth phases of the St. Lucia Estuary

Table 1. Physicochemical variables, microphytobenthic (MPB) and phytoplankton (PPL) biomass measured at each station during the different mouth phases (mean \pm SE). NTU: Nephelometric Turbidity Units

\begin{tabular}{|c|c|c|c|c|c|c|c|c|}
\hline $\begin{array}{l}\text { Mouth } \\
\text { phase }\end{array}$ & Station & 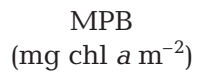 & $\begin{array}{c}\text { PPL } \\
\left(\mathrm{mg} \mathrm{chl} a \mathrm{~m}^{-3}\right)\end{array}$ & $\begin{array}{l}\text { Depth } \\
\text { (m) }\end{array}$ & $\begin{array}{l}\text { Oxygen } \\
\left(\mathrm{mg} \mathrm{l}^{-1}\right)\end{array}$ & $\begin{array}{c}\text { Salinity } \\
\text { (ppt) }\end{array}$ & $\begin{array}{c}\text { Temperature } \\
\left({ }^{\circ} \mathrm{C}\right)\end{array}$ & $\begin{array}{l}\text { Turbidity } \\
\text { (NTU) }\end{array}$ \\
\hline \multirow[t]{5}{*}{ Closed } & Mouth & $54.1 \pm 24.2$ & $22.3 \pm 9.96$ & $1.34 \pm 0.60$ & $8.99 \pm 4.02$ & $13.2 \pm 5.88$ & $25.5 \pm 11.4$ & $6.76 \pm 3.02$ \\
\hline & Esengeni & $43.7 \pm 19.6$ & $25.0 \pm 11.2$ & $0.83 \pm 0.37$ & $7.75 \pm 3.47$ & $6.45 \pm 2.88$ & $24.5 \pm 11.0$ & $28.7 \pm 12.8$ \\
\hline & Catalina Bay & $189 \pm 84.7$ & $26.7 \pm 11.9$ & $0.38 \pm 0.17$ & $9.06 \pm 4.05$ & $14.5 \pm 6.49$ & $24.8 \pm 11.1$ & $42.8 \pm 19.1$ \\
\hline & Charters Creek & $176 \pm 78.7$ & $40.9 \pm 18.3$ & $0.09 \pm 0.04$ & $8.38 \pm 4.19$ & $24.0 \pm 12.0$ & $29.2 \pm 14.6$ & $41.4 \pm 18.5$ \\
\hline & Listers Point & $143 \pm 63.9$ & $116 \pm 52.0$ & $0.12 \pm 0.05$ & $4.96 \pm 2.48$ & $44.0 \pm 22.0$ & $29.8 \pm 14.9$ & $85.8 \pm 38.4$ \\
\hline \multirow[t]{5}{*}{ Open } & Mouth & $19.9 \pm 11.5$ & $13.4 \pm 7.75$ & $0.13 \pm 0.08$ & $7.57 \pm 4.37$ & $34.6 \pm 20.0$ & $23.1 \pm 13.3$ & $24.4 \pm 14.1$ \\
\hline & Esengeni & $23.0 \pm 16.3$ & $24.7 \pm 17.5$ & $0.83 \pm 0.58$ & $6.78 \pm 4.79$ & $33.9 \pm 24.0$ & $21.4 \pm 15.1$ & $41.2 \pm 29.1$ \\
\hline & Catalina Bay & $86.2 \pm 49.7$ & $7.09 \pm 4.09$ & $0.72 \pm 0.42$ & $7.50 \pm 4.33$ & $29.1 \pm 16.8$ & $23.7 \pm 13.7$ & $8.37 \pm 4.83$ \\
\hline & Charters Creek & $154 \pm 89.0$ & $26.7 \pm 15.4$ & $0.29 \pm 0.17$ & $8.51 \pm 4.92$ & $29.7 \pm 17.2$ & $25.5 \pm 14.7$ & $20.7 \pm 12.0$ \\
\hline & Listers Point & $62.0 \pm 35.8$ & $23.8 \pm 13.8$ & $0.29 \pm 0.17$ & $6.91 \pm 3.99$ & $35.1 \pm 20.2$ & $23.8 \pm 13.7$ & $32.8 \pm 18.9$ \\
\hline \multirow[t]{5}{*}{ Re-closed } & Mouth & $23.2 \pm 10.4$ & $15.9 \pm 7.10$ & $0.58 \pm 0.26$ & $5.24 \pm 2.62$ & $24.5 \pm 11.0$ & $21.6 \pm 9.7$ & $20.9 \pm 10.5$ \\
\hline & Esengeni & $12.6 \pm 5.61$ & $23.7 \pm 10.6$ & $1.58 \pm 0.70$ & $6.00 \pm 3.00$ & $27.2 \pm 12.2$ & $21.3 \pm 9.52$ & $49.6 \pm 24.8$ \\
\hline & Catalina Bay & $26.1 \pm 11.7$ & $1.96 \pm 0.88$ & $1.52 \pm 0.68$ & $5.04 \pm 2.52$ & $37.1 \pm 16.6$ & $24.1 \pm 10.8$ & $10.6 \pm 5.28$ \\
\hline & Charters Creek & $10.4 \pm 4.65$ & $7.25 \pm 3.24$ & $0.22 \pm 0.10$ & $7.16 \pm 3.58$ & $49.4 \pm 22.1$ & $23.7 \pm 10.6$ & $186 \pm 93.1$ \\
\hline & Listers Point & $5.81 \pm 2.60$ & $22.2 \pm 9.95$ & $0.24 \pm 0.11$ & $7.57 \pm 3.78$ & $49.1 \pm 22.0$ & $21.0 \pm 9.37$ & $234 \pm 117$ \\
\hline
\end{tabular}


1.8 at Esengeni in February 2007 to 86.9 at Listers Point in February 2006. During the open phase, salinities were generally marine (35), but the reversed salinity gradient re-established once again after mouth re-closure.

Average water temperatures ranged between 15.2 and $34.8^{\circ} \mathrm{C}$ in summer, 19.7 and $25.2^{\circ} \mathrm{C}$ in autumn, 17.2 and $24.4^{\circ} \mathrm{C}$ in winter and 22.5 and $30.5^{\circ} \mathrm{C}$ in spring. Dissolved oxygen was highly variable throughout the survey, with values ranging from $1.92 \mathrm{mg} \mathrm{O}_{2} \mathrm{l}^{-1}$ at Listers Point in November 2006 to $11.9 \mathrm{mg} \mathrm{O}_{2} \mathrm{l}^{-1}$ at Esengeni in November 2006. Turbidity ranged from 1 NTU at Catalina Bay to 341 NTU at Charters Creek. The highest turbidities were generally recorded at Esengeni, Charters Creek and Listers Point (Table 1).

\section{Phytoplankton and microphytobenthic biomass}

Phytoplankton biomass ranged from 1.49 to $421 \mathrm{mg}$ chl a m $\mathrm{m}^{-3}$ during the study period. Biomass peaked during the closed phase, with maximum phytoplankton biomass recorded in the northern regions of the lake. Biomass in the Mouth and Narrows was substantially lower. During the open and re-closed mouth phases, biomass was generally uniform across all stations (Table 1).

Microphytobenthic biomass ranged from 0.47 to $451 \mathrm{mg} \mathrm{chl} \mathrm{a} \mathrm{m}{ }^{-2}$ during the study period. There was a significant difference between mouth states $\left(F_{2,58}=\right.$ $6.75, \mathrm{p}<0.01)$. Like phytoplankton biomass, microphytobenthic biomass was also greater in the closed phase and was also generally greater in the northern regions of the lake (Table 1). These variations were, however, not significantly different either spatially or seasonally $(\mathrm{p}>0.05)$.

\section{Zooplankton}

Total recorded zooplankton abundance in the St. Lucia Estuary ranged from 53.5 to $13.4 \times 10^{4}$ ind. $\mathrm{m}^{-3}$ during the study period (Table 2). Abundance varied between mouth states $\left(F_{2,61}=5.04, p<0.01\right.$, Fig. 2a), peaking after mouth re-closure. Abundance was greatest at the Mouth and Esengeni during the closed phase. During the open phase, zooplankton abundance was low throughout the lake system, showing no spatial variation $\left(F_{4,9}=0.579, \mathrm{p}>0.05\right)$. After mouth re-closure, densities escalated to a maximum of $13.4 \times$ $10^{4}$ ind. $\mathrm{m}^{-3}$ at Esengeni. While zooplankton were recorded at Charters Creek and Listers Point after the mouth breached, densities diminished by October 2008 when hypersaline conditions again persisted (Fig. 3).
Abundance of the mysid Mesopodopsis africana was greatest at the Mouth and Esengeni during the closed phase, but was virtually zero throughout the system during the open-mouth phase. After mouth re-closure, high densities of $M$. africana were recorded in the South Lake stations. Small populations were also recorded at Listers Point in November 2007 (Fig. 3b). The copepod Pseudodiaptomus stuhlmanni was present at all stations except Listers Point during the closed phase. Densities decreased during the openmouth period and increased again after mouth re-closure at all stations except the Mouth. Densities during the re-closure period were higher than those previously recorded, especially at Esengeni (Fig. 3c). Abundance of another copepod, Acartia natalensis, was greatest at the Mouth and Esengeni during the closed phase and increased substantially to a maximum of $5.6 \times 10^{4}$ ind. $\mathrm{m}^{-3}$ in July 2008 (Fig. 3d).

Mean zooplankton biomass recorded by Grindley (1982) for the 5 main areas of the St. Lucia system during the period 1967-1974 are compared with biomass data generated from the present study in Fig. 4. There was an increase in biomass from 1967 to 1974 corresponding with an increase in freshwater flow. Although 2006 was during the peak of the drought, biomass during this year was within the range of that in 1974 .

Data from the present study confirmed a significant difference in biomass between mouth states $\left(F_{2,60}=\right.$ 7.21, p < 0.05, Fig. 2b). Biomass during the re-closed phase was significantly greater than in the closed and open phases (post hoc Tukey's test, p < 0.05). Biomass was also generally greatest at the Mouth and Esengeni and lower in the lakes during the closed phases $(\mathrm{p}<$ 0.05). The opposite was true for the open phase (Fig. 2b); however, the differences were not significant ( $p>0.05$ ). Following mouth re-closure, average biomass ranged from 81.6 to $676 \mathrm{mg} \mathrm{DW} \mathrm{m}^{-3}$, but spatial variation was not significant $\left(F_{4,20}=2.01, \mathrm{p}>0.05\right)$.

Zooplankton species richness was significantly higher during open-mouth conditions (post hoc Tukey's test, $\mathrm{p}<0.05$, Fig. 2c). During the closed phase, diversity at the Mouth and Esengeni was significantly greater than that at Charters Creek and Listers Point $(p<0.05)$. In the open phase, peaks in species richness were recorded at the Mouth and Esengeni. Following mouth re-closure, species richness was roughly uniform throughout the system, ranging from 5 taxa at Charters Creek to 13 taxa at the Mouth (Table 2).

\section{Community structure}

A total of 69 different taxa were recorded during the entire study period, 27 of which were present during the closed phase, 51 during the open phase and 33 dur- 
$\rightarrow$ Mouth $\rightarrow$ Esengeni $\rightarrow$ Catalina Bay $\rightarrow$ Charters Creek $\bullet$ Listers Point
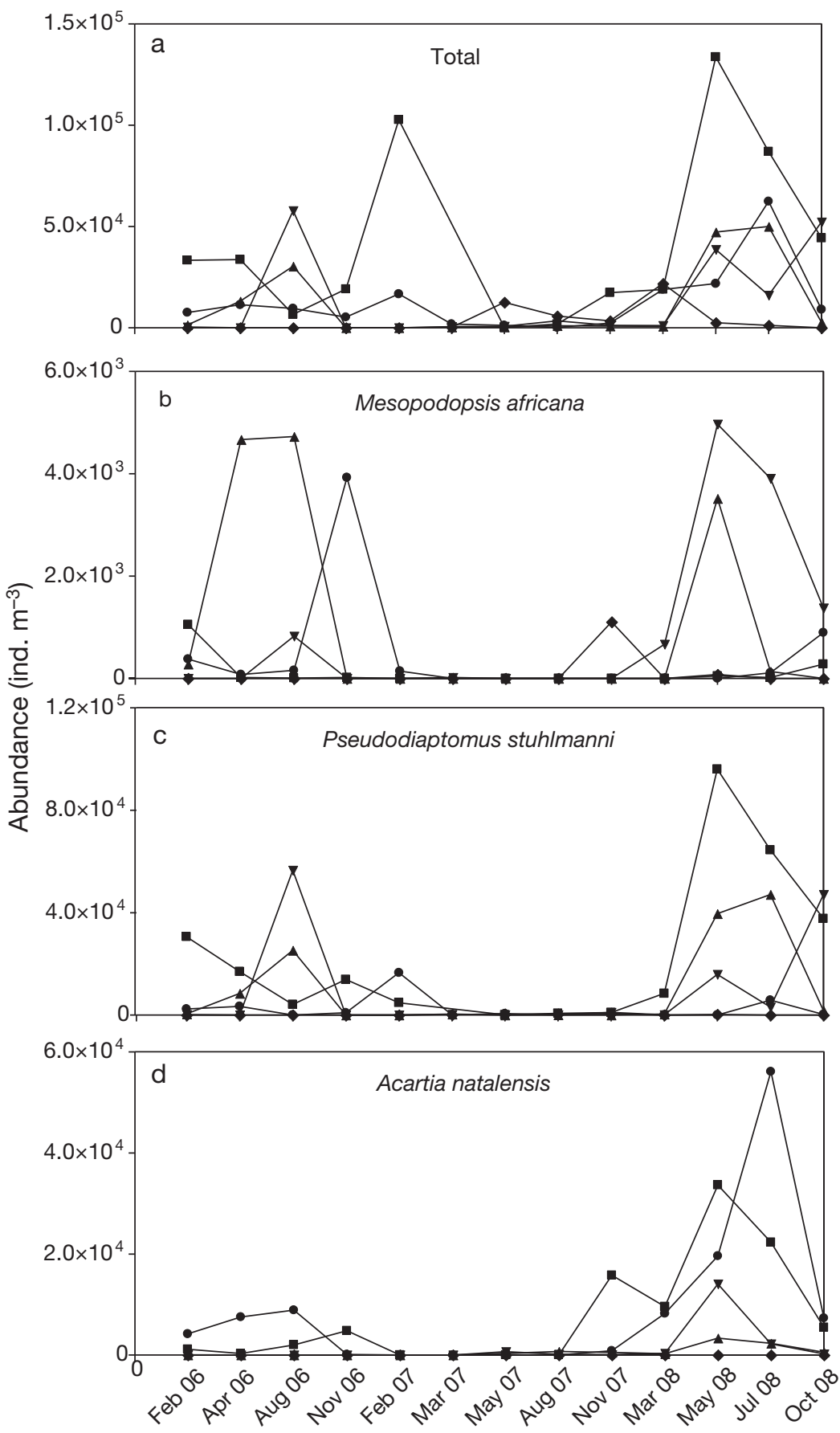

Fig. 3. Mesopodopsis africana, Pseudodiaptomus stuhlmanni and Acartia natalensis. Average seasonal densities of total zooplankton and the 3 most dominant taxa in the St. Lucia Estuary throughout the study period

ing the re-closed phase (Table 3). A number of taxa were introduced when the estuary mouth breached. These included various harpacticoid copepods, such as Macrosetella sp., Euterpina acutifrons and Metis sp., calanoids such as Eucalanus sp. and Mesocalanus sp., as well as poecilostomatoids, Oncaea spp. and Corycaeus spp. Other marine recruits which were previously excluded, such as the prawn Penaeus indicus, were also recorded following the breaching event.

Cluster analysis and MDS plots (Fig. 5) showed that zooplankton communities differed between the openand closed-mouth states, and was statistically confirmed by ANOSIM $(\mathrm{R}=$ 0.838, $\mathrm{p}<0.01$ ). Sites within the closedmouth cluster showed between 40 and $80 \%$ similarity, while those in the openmouth cluster were more dissimilar, showing only 15 to $55 \%$ similarity. The zooplankton community present at Listers Point subsequent to the re-closure of the estuary's mouth was an anomalous data point, as it grouped in the open-mouth cluster.

The dominant taxa during the closed phases were the calanoid copepods Pseudodiaptomus stuhlmanni and Acartia natalensis, contributing on average 74.1 and $17.9 \%$ to total zooplankton abundance, respectively. These taxa made a cumulative contribution of $92 \%$ to total zooplankton density. Although the abundance of $P$. stuhlmanni and A. natalensis decreased significantly during the openmouth phase, they still accounted for $74 \%$ of the total zooplankton assemblage. The remaining contributors were Euterpina acutifrons (11.2\%), gastropod veligers $(3.07 \%)$ and copepod nauplii $(2.9 \%)$.

Data analysis using the SIMPER routine revealed that $90.7 \%$ of the dissimilarity between the open and closed phases was due to 8 different taxa (Table 4). These included Pseudodiaptomus stuhlmanni $(48.3 \%)$, Acartia natalensis $(25 \%)$, Mesopodopsis africana (5.18\%), Halicylops spp. (3.77\%), Cletocamptus spp. (3.27\%), gastropod veligers $(2.23 \%)$, polychaete larvae $(1.54 \%)$ and Euterpina acutifrons $(1.4 \%)$.

With the exception of Listers Point during the closed phase, cluster analysis showed all stations to be $>30 \%$ similar during each of the mouth phases. Zooplankton communities at Catalina Bay and Charters Creek, as well as at the Mouth and Esengeni, consistently 


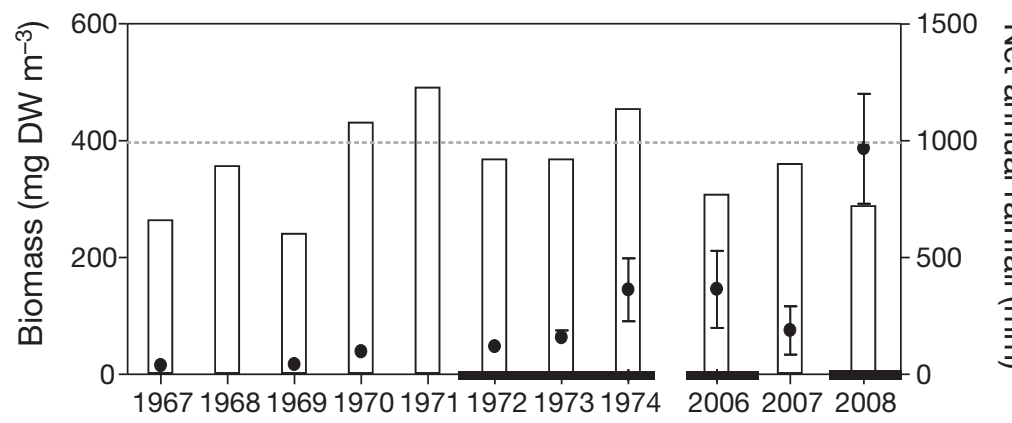

Fig. 4. Time series of average $( \pm \mathrm{SE})$ zooplankton biomass $(\bullet)$ from 1967 to 1974 (Grindley 1982) and from 2006 to 2008 in the St. Lucia Estuary. White bars show the net annual rainfall and the dotted line represents the average net annual rainfall for St. Lucia. Thick lines along the $x$-axis indicate periods of closed-mouth conditions

grouped together during each of the mouth phases, but communities at Listers Point were always separated from any of the above (Fig. 6). ANOSIM also confirmed significant spatial variability in zooplankton assemblages within each mouth state. Most notable was the difference between the Mouth and all other stations after mouth re-closure $(\mathrm{R}=0.29, \mathrm{p}<0.05)$. While the zooplankton communities at all other stations were characterised by typical St. Lucia zooplankton, the Mouth was dominated by Oikopleura dioica and Acartia natalensis. O. dioica entered the estuary during the open-mouth state and, upon re-closure, appeared to flourish in co-existence with $A$. natalensis, reaching a maximum abundance of $10^{4}$ ind. $\mathrm{m}^{-3}$ up to 5 mo after mouth closure. However, in May 2008, the O. dioica population dwindled, leaving $A$. natalensis as the single dominant species in the area. Only in July 2008 did the zooplankton community structure at the Mouth start resembling that observed prior to mouth breaching, with Mesopodopsis africana and Pseudodiaptomus stuhlmanni once again making a substantial contribution to the total zooplankton biomass (Fig. 7).

The BIOENV procedure identified different environmental variables influencing the zooplankton communities. Overall, interactions between microphytobenthic biomass, phytoplankton biomass, salinity and temperature best explained the patterns observed in the zooplankton assemblages $(\mathrm{R}=0.37)$. Within the closed phase, interactions between microphytobenthic biomass, phytoplankton, dissolved oxygen, salinity and temperature best explained zooplankton distribution $(\mathrm{R}=$ 0.31). Microphytobenthic biomass and dissolved oxygen were the primary determinants during the openmouth phase, while after mouth re-closure, water depth, salinity and temperature explained most of the variation in zooplankton $(\mathrm{R}=0.38)$.

Spearman's rank correlation between environmental parameters and zooplankton diversity, density and biomass showed few significant correlations (Table 5). On the whole, zooplankton abundance, biomass and species richness were inversely related to microphytobenthic biomass. Zooplankton abundance and species richness correlated positively with water depth and negatively with temperature. Additionally, a negative relationship existed between zooplankton abundance and salinity. Within the closed phase, zooplankton biomass and species richness were also inversely related

Table 2. Total zooplankton abundance, biomass and species richness recorded across all stations within the St. Lucia Estuary during the study period. N/W: stations without water

\begin{tabular}{|c|c|c|c|c|c|c|c|c|c|c|c|c|c|}
\hline \multirow{2}{*}{$\begin{array}{l}\text { Mouth } \\
\text { phase }\end{array}$} & \multirow{2}{*}{ Station } & \multicolumn{4}{|c|}{ — Abundance (ind. $\mathrm{m}^{-3}$ ) } & \multicolumn{4}{|c|}{ —Biomass (mg DW $\left.\mathrm{m}^{-3}\right)-$} & \multicolumn{4}{|c|}{ Species richness (no. of taxa) } \\
\hline & & Mean & $\mathrm{SE}$ & Min & Max & Mean & $\mathrm{SE}$ & Min & Max & Mean & $\mathrm{SE}$ & Min & Max \\
\hline \multirow{5}{*}{ Closed } & Mouth & 10108 & 1954 & 5270 & 16768 & 145 & 67.9 & 24.5 & 391 & 8.8 & 1.2 & 6 & 13 \\
\hline & Esengeni & 39093 & 16676 & 6619 & 10269 & 151 & 49.8 & 22.8 & 294 & 8 & 0.8 & 5 & 10 \\
\hline & Catalina Bay & 9017 & 5890 & 0 & 30408 & 287 & 254 & 0 & 1302 & 4.8 & 1.7 & 0 & 10 \\
\hline & Charters Creek & 11649 & 11553 & 0 & 57861 & 71.8 & 62.8 & 0 & 321 & 2.6 & 1.6 & 0 & 7 \\
\hline & Listers Point & N/W & N/W & N/W & N/W & N/W & N/W & N/W & N/W & N/W & N/W & N/W & N/W \\
\hline \multirow[t]{5}{*}{ Open } & Mouth & 1113 & 499 & 188 & 1901 & 10.7 & 3.3 & 4.1 & 14.9 & 21 & 4.5 & 16 & 30 \\
\hline & Esengeni & 1045 & 859 & 186 & 1904 & 10.3 & 8.6 & 1.8 & 18.9 & 17 & 5 & 12 & 22 \\
\hline & Catalina Bay & 625 & 196 & 404 & 1017 & 5.8 & 1.1 & 4.7 & 7.9 & 4.7 & 1.2 & 3 & 7 \\
\hline & Charters Creek & 1612 & 900 & 623 & 3409 & 25 & 16.2 & 5.1 & 57 & 8 & 3.6 & 3 & 15 \\
\hline & Listers Point & 6223 & 3589 & 223 & 12636 & 294 & 274 & 2 & 841 & 4 & 1.5 & 2 & 7 \\
\hline \multirow[t]{5}{*}{ Re-closed } & Mouth & 20674 & 10914 & 2313 & 62394 & 114.5 & 40.9 & 23.2 & 253 & 9 & 1.1 & 7 & 13 \\
\hline & Esengeni & 60270 & 22261 & 17372 & 133675 & 454 & 143 & 104 & 871 & 7.6 & 0.5 & 6 & 9 \\
\hline & Catalina Bay & 20350 & 11585 & 782 & 50076 & 340 & 233 & 8.2 & 1215 & 7.6 & 0.5 & 6 & 9 \\
\hline & Charters Creek & 21870 & 10224 & 1184 & 52213 & 676 & 257 & 16.7 & 1363 & 8 & 1 & 5 & 10 \\
\hline & Listers Point & 2055 & 628 & 0 & 3419 & 81.6 & 47.5 & 0 & 260 & 5.6 & 1.6 & 0 & 9 \\
\hline
\end{tabular}



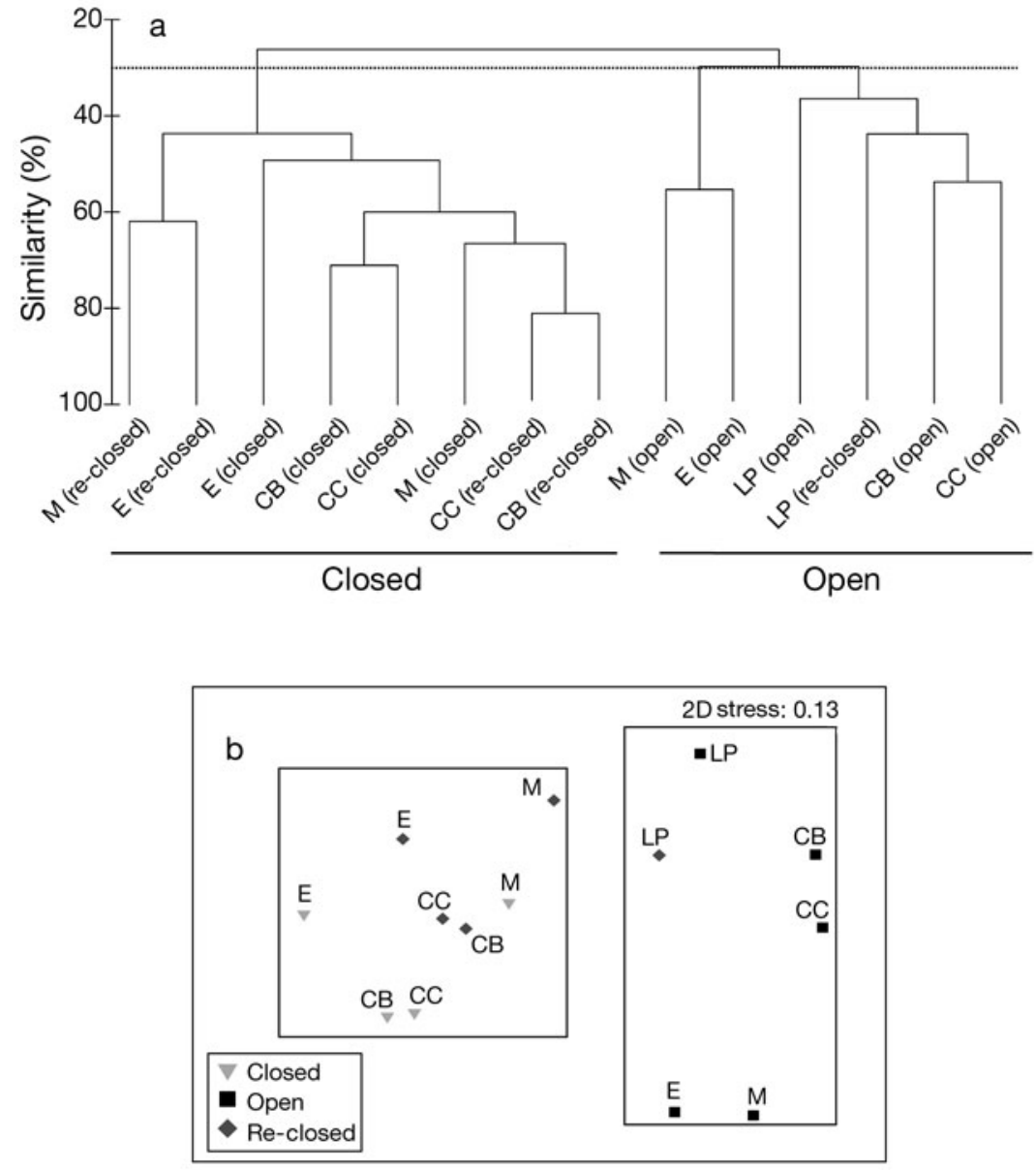

Fig. 5. (a) Dendrogram and (b) multidimensional scaling ordination showing the grouping of zooplankton communities during closed, open and re-closed mouth phases of the St. Lucia Estuary. Dotted line in (a) represents 35\% similarity. M: Mouth; E: Esengeni; CB: Catalina Bay; CC: Charters Creek; LP: Listers Point

to microphytobenthic biomass, while negative correlations existed between zooplankton abundance and salinity as well as temperature. During the openmouth and re-closure phases, microphytobenthic biomass was the only parameter to significantly correlate with zooplankton species richness, positively during the closed-mouth phase and negatively during the open-mouth phase.

\section{DISCUSSION}

As has been previously observed in most South African estuaries, maximum zooplankton abundance and biomass in the St. Lucia Estuary were recorded during the closed phase (Whitfield 1980, Kibirige \& Perissinotto 2003, Kibirige et al. 2006). This is due to a combination of stable conditions, limited freshwater input and minimal exchange of water with the sea
(Gaughan \& Potter 1995, Perissinotto et al. 2000). Low zooplankton abundance and biomass during open-mouth conditions are consistent with findings reported in the literature and are linked to the export of biomass-rich estuarine water into the ocean (Froneman 2004).

In Grindley's (1982) study of zooplankton biomass in the St. Lucia system (1967-1974), which covered both open- and closed-mouth phases and extreme salinity fluctuations, peaks in biomass corresponded with freshwater pulses (Grindley 1982). It is, therefore, not surprising to find no seasonal variation in total zooplankton biomass during the present study, since the survey took place during harsh drought conditions, with little freshwater input. Biomass was generally highest at the Mouth and Narrows and substantially lower in the lakes during the closed phase. This is because the northern regions were most severely affected by the drought, culminating in reduced water levels and greater salinity and temperature. Conversely, zooplankton biomass was greater in the lakes during open-mouth conditions. These findings correspond with those of Grindley (1982) and can be attributed to the lakes being a more stable environment under open-mouth conditions. Biomass levels recorded at the peak of the drought (2006) during the present study were generally within the range of those recorded by Grindley (1982) in 1974, despite the above-average rainfall which the area received during that year. Comparisons between these studies must, however, be taken with caution for the following reasons. (1) Grindley (1982) used 2 different sampling methods, a ring-net $(30 \mathrm{~cm}$ diameter, $90 \mu \mathrm{m}$ mesh) and a Clarke Bumpus sampler $(12.5 \mathrm{~cm}$ diameter, $125 \mu \mathrm{m}$ mesh). (2) All samples were taken at the surface (hand-held) and next to the boat gunnels, thereby creating substantial disturbance (T. H. Wooldridge pers. comm.). (3) Sampling frequency and intensity were not consistent.

In this study, biomass peaked after mouth re-closure, exceeding levels which were recorded both during the present study and that of Grindley (1982). Inflowing marine water may have aided the buildup in zooplankton biomass during the subsequent closed phase, as was previously observed in the Kasouga Estuary (Froneman 2004). On a regional scale, biomass records 
Table 3. Spatial variations in average zooplankton density during the different mouth phases at the 5 representative stations within the St. Lucia Estuary. M: Mouth; E: Esengeni; CB: Catalina Bay; CC: Charters Creek; LP: Listers Point. Unid.: unidentified

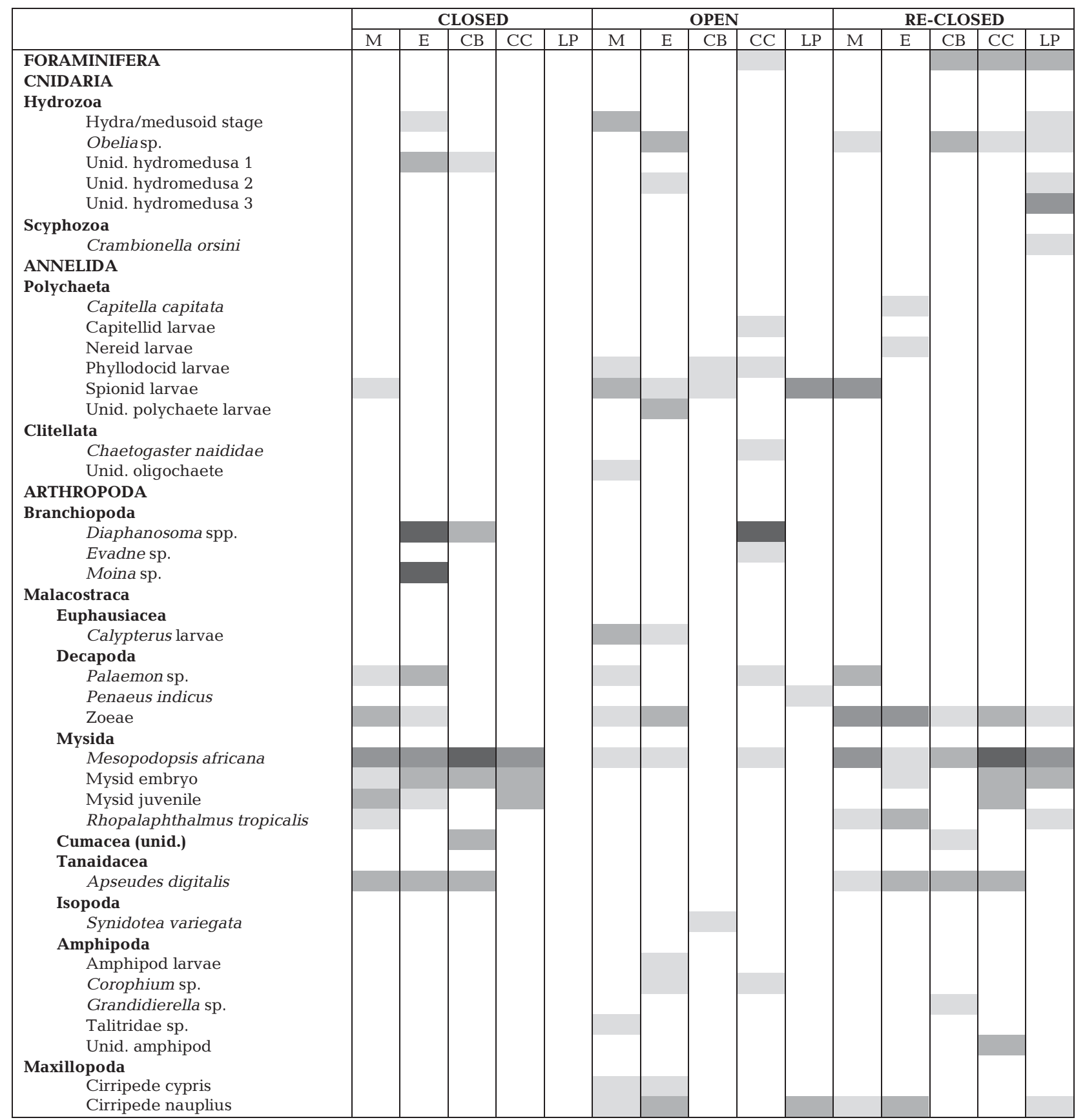

were generally within the range of those reported by Wooldridge (1999) for South African estuaries. In fact, even some of the lowest values recorded during the present study exceeded those documented in temperate north systems, such as the Patuxent River, Narragansett Bay and Westerschelde (Heip et al. 1995 and references therein).

Prolonged periods of mouth closure in temporarily open/closed estuaries are generally associated with low levels of zooplankton taxonomic diversity (Froneman 2004, Perissinotto et al. 2004). In the present study, the lake zooplankton was, like most estuarine zooplankton assemblages in southern Africa (Wooldridge 1999), dominated by typical estuarine taxa, such as Pseudodiaptomus stuhlmanni, Acartia natalensis and Mesopodopsis africana, which often collectively contributed over $90 \%$ of the total zooplankton abundance. The zooplankton assemblages of the St. Lucia 
Table 3 (continued)

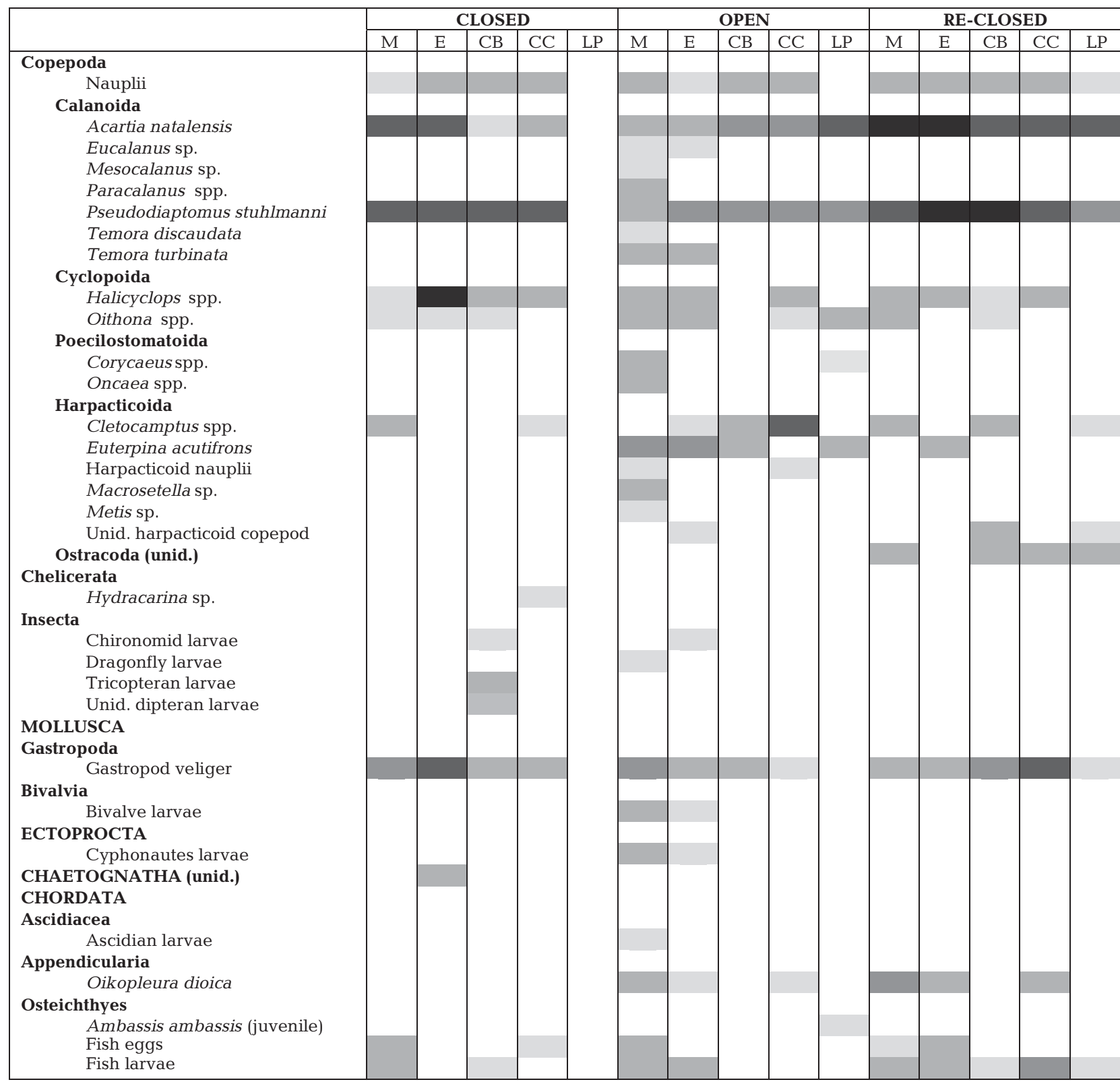

\begin{tabular}{|c|c|c|c|c|c|}
\hline Code & & & & & \\
\hline Density (ind. $\mathrm{m}^{-3}$ ) & $1-9$ & $10-99$ & $100-999$ & $1000-9999$ & $10000-99999$ \\
\hline
\end{tabular}

Estuary, as described by Grindley (1982), were generally made up of: (1) a stenohaline marine component, consisting of copepods such as Corycaeus spp., which tidally accessed the mouth; (2) a euryhaline marine component, including species of Paracalanus, which were able to penetrate a little further; and (3) a freshwater component, consisting of species such as Diaptomus spp. and Cyclops spp., found at the mouths of inflowing rivers. Only 27 of the 95 previously recorded taxa (Grindley 1976) were observed in the system during the closed-mouth phase. Missing components included marine and freshwater taxa, which were absent because of prolonged reduced freshwater input (Allanson \& Read 1995) and the closed-mouth state which prevented tidal exchange. Primo et al. (2009) showed that dry periods in the downstream stations of the permanently open Mondego Estuary (Portugal) were also characterised by a lack of seasonality, low taxonomic 
Table 4. Zooplankton taxa accounting for $90.7 \%$ of the dissimilarity between the 2 clusters (viz. open and closed) identified using dendrograms and multidimensional scaling ordinations from SIMPER

\begin{tabular}{|c|c|c|c|c|}
\hline \multirow[t]{2}{*}{ Species } & \multicolumn{2}{|c|}{$\begin{array}{c}\text { Average abundance } \\
\text { (ind. } \mathrm{m}^{-3} \text { ) }\end{array}$} & \multirow[t]{2}{*}{$\begin{array}{l}\% \text { contri- } \\
\text { bution }\end{array}$} & \multirow{2}{*}{$\begin{array}{c}\text { \% cumu- } \\
\text { lative } \\
\text { contribution }\end{array}$} \\
\hline & Closed & Open & & \\
\hline Pseudodiaptomus stuhlmanni & i 9883 & 261 & 48.3 & 48.3 \\
\hline Acartia natalensis & 4061 & 1121 & 25.0 & 73.3 \\
\hline Mesopodopsis africana & 612 & 1.54 & 5.18 & 78.5 \\
\hline Halicyclops spp. & 1287 & 16.3 & 3.77 & 82.2 \\
\hline Cletocamptus spp. & 3.98 & 213 & 3.27 & 85.5 \\
\hline Gastropod veliger & 490 & 33.9 & 2.23 & 87.7 \\
\hline Polychaete larvae & 29.3 & 185 & 1.54 & 89.3 \\
\hline Euterpina acutifrons & 0.93 & 72.6 & 1.40 & 90.7 \\
\hline
\end{tabular}

cruited into the system. The timing of the mouth breaching allowed the autumn cohort of $P$. indicus to enter the estuary. This cohort would usually overwinter in the estuary and return to sea the next spring (Benfield et al. 1989), but was prevented from doing so due to the reformation of the beach berm by 24 August 2007.

Because this breaching event took place during a drought, it is not surprising that there was still a general lack of freshwater zooplankton. Groundwater seepage points along the eastern shores have been hypothesised to form microhabitats of reduced salinity, capable of acting as reservoirs during dry cycles and providing refugia for estuarine species, for later recolonisation of the estuary (Taylor et al. 2005). However, data from an allied study carried out in 2005 (S. Singh unpubl. data) showed that the zooplankton communities of these refugia are significantly different from those of neighbouring sites and, therefore, probably not the primary source of recolonisation and recruitment. It is more likely that some species of zooplankton may be able to produce resting stages or eggs capable of surviving dry or hypersaline conditions for long periods of time (e.g. Uye 1985, William-Howze 1997, Engel 2005). Recolonisation could also have occurred from adjacent parts of the estuary that had not dried out completely during the drought (e.g. the Narrows or the southern part of South Lake).

Abundance of the mysid Mesopodopsis africana decreased drastically after the system breached, becoming almost entirely absent within a month. Possible explanations may include reduced water levels in the mouth region as a result of sediment deposition, populations being flushed out to sea (e.g. Wooldridge 1986, Kibirige \& Perissinotto 2003) or increased predation

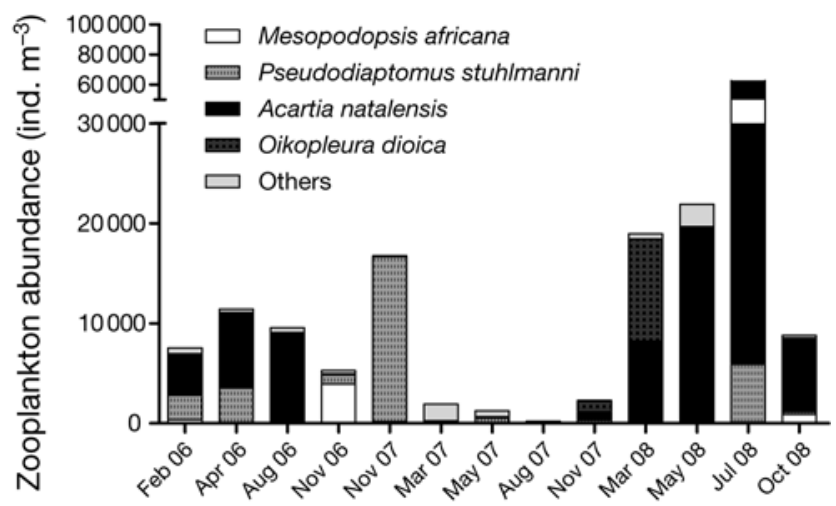

Fig. 7. Average abundance of the dominant zooplankton taxa at the Mouth of the St. Lucia Estuary during the study period
Fig. 6. Dendrograms showing spatial variation in community structure during the (a) closed, (b) open and (c) re-closed mouth phases of the St. Lucia Estuary during the study period. Station codes are as in Fig. 5 
Table 5. Spearman's rank correlation between physicochemical parameters and diversity, abundance and biomass of zooplankton during the different mouth phases of the St. Lucia Estuary. MPB: microphytobenthic biomass; PPL: phytoplankton biomass; ${ }^{*}: \mathrm{p}<0.05{ }^{* *}: \mathrm{p}<0.01$

\begin{tabular}{|lllrrrrrr|}
\hline Mouth phase & Parameter & MPB & PPL & Depth & Oxygen & Salinity & Temperature & Turbidity \\
\hline Closed & Biomass & $-0.58^{* *}$ & -0.07 & 0.06 & 0.09 & -0.37 & -0.33 & -0.09 \\
& Abundance & -0.40 & 0.13 & 0.15 & 0.21 & $-0.46^{*}$ & $-0.45^{*}$ & -0.03 \\
& Diversity & $-0.58^{* *}$ & 0.03 & 0.48 & 0.22 & -0.50 & -0.41 & -0.22 \\
Open & Biomass & -0.34 & 0.18 & -0.06 & -0.05 & -0.20 & -0.32 & -0.08 \\
& Abundance & -0.35 & 0.13 & -0.09 & -0.10 & -0.19 & -0.33 & -0.05 \\
& Diversity & $-0.58^{*}$ & -0.01 & 0.24 & -0.04 & 0.02 & -0.47 & 0.16 \\
Re-closed & Biomass & -0.27 & 0.15 & 0.09 & -0.01 & -0.18 & 0.15 & 0.26 \\
& Abundance & -0.21 & 0.26 & 0.33 & 0.11 & -0.34 & 0.01 & 0.06 \\
Overall & Diversity & $0.57^{*}$ & -0.12 & 0.18 & -0.19 & -0.19 & 0.17 & -0.29 \\
& Biomass & $-0.44^{* *}$ & 0.04 & 0.16 & 0.07 & -0.17 & -0.22 & 0.10 \\
& Abundance & $-0.37^{* *}$ & 0.12 & $0.27^{*}$ & 0.16 & $-0.27^{*}$ & $-0.31^{*}$ & 0.06 \\
& Diversity & $-0.38^{* *}$ & -0.01 & $0.36^{*}$ & 0.01 & 0.01 & $-0.33^{*}$ & -0.05 \\
\hline
\end{tabular}

pressure by fish that entered the estuary from the ocean. In the present study, mysid swarms were mostly restricted to the mouth region during the closed phase, but were recorded in low numbers, along with Pseudodiaptomus stuhlmanni and Acartia natalensis at Charters Creek and Listers Point after the estuary breached. It is likely that the more favourable conditions (viz. increased water level and decreased salinity) allowed for the development of these communities in the northern lakes, which was probably a more stable environment than the Mouth and the Narrows at the time.

Multivariate correlations showed weak associations of zooplankton with environmental parameters in the estuary. This is not uncommon in estuaries (Hastie \& Smith 2006) and is probably a product of the highly dynamic nature of this system. Overall, the interaction between microphytobenthic biomass, phytoplankton biomass, salinity and temperature best explained the variation in community structure. In terms of univariate variables, microphytobenthic biomass was inversely related to zooplankton biomass, abundance and species richness. Reduced grazing pressure could have allowed for microphytobenthos proliferation, since biomass was generally greatest at Charters Creek and Listers Point, where conditions were often not favourable for the survival of zooplankton. Similar findings were reported by Pillay \& Perissinotto $(2008,2009)$ for the benthic communities of the St. Lucia Estuary. Overall, zooplankton abundance and species richness correlated positively with water depth. Such a relationship is expected, since habitat for zooplankton increases with water depth. Additionally, the Mouth and narrows are deeper stations, partly protected from the effects of drought due to the freshwater inflow at Makakatana, Mfolozi and Mpate Rivers. Zooplankton abundance and salinity were negatively correlated, reflecting the negative impact of hypersaline condi- tions on zooplankton abundance. Additionally, zooplankton abundance and species richness were greater in cooler waters. This could be a product of the shallower waters (e.g. Charters Creek and Listers Point) being more susceptible to heating. This negative correlation is, therefore, probably more related to depth than temperature itself, since water temperature decreases with depth. High temperature is nevertheless known and expected to negatively affect the physiology of many zooplankton species (e.g. Moore et al. 1996, Norberg \& De Angelis 1997).

Zooplankton dynamics at the mouth of the St. Lucia Estuary followed a very unique pattern, particularly after mouth re-closure. High abundances of the appendicularian Oikopleura dioica $\left(>10^{4}\right.$ ind. $\left.\mathrm{m}^{-3}\right)$ were found. These tunicates live in individual mucous cases, which efficiently concentrate and collect particulate matter from the water (Deibel 1998). While appendicularians commonly occur in permanently open estuaries, there are no reports of $O$. dioica swarms thriving in estuaries under closed-mouth conditions. Studies have shown that other planktonic grazers are often rare or absent in swarms of planktonic tunicates (Fraser 1962, Berner 1967, Deibel 1980). Several factors may contribute to this apparent exclusion of other herbivores. Firstly, high reproductive rates enable planktonic tunicates to exploit food sources more rapidly (Heron 1972, Deibel 1980). Also, appendicuarians are food generalists, capable of ingesting a wide size spectrum of naturally occurring particles (Deibel 1998). Particle consumption by tunicates may, therefore, reduce the food available to juvenile stages of other herbivores, decreasing recruitment of competing zooplankton. Finally, the exceptionally high filtering rates of most tunicates could reduce phytoplankton standing stocks to levels that would not support other grazers. In older swarms, both copepods and appendicularians may 
coexist in high densities, suggesting that, given enough time and sufficient food, herbivores with longer generation times could also exploit the same phytoplankton stocks (Alldredge \& Madin 1982).

With the arrival of Oikopleura dioica in the St. Lucia Estuary, the zooplankton community structure in the Mouth area shifted drastically from being dominated by Mesopodopsis africana and Pseudodiaptomus stuhlmanni, which used to make up the bulk of the biomass, to being dominated by $O$. dioica and Acartia natalensis. There are several possible explanations for the apparent exclusion of these larger taxa. Firstly, it is possible that changes in the physical environment associated with the re-closure of the estuary mouth (e.g. a decrease in turbidity and an increase in water level) favoured $O$. dioica, to the exclusion of the other grazers. Secondly, O. dioica, with its efficient feeding mode (Alldredge 1981, Deibel 1998) may have outcompeted $P$. stuhlmanni. Thirdly, the slower regeneration times of copepods such as P. stuhlmanni (e.g. Paracalanus crassirostris versus $O$. dioica ratio of $\approx 1: 10$, Hopcroft \& Roff 1995) may have made it vulnerable to predation, with the opposite being true for $O$. dioica. Lastly, heavy fish predation may have limited populations of $M$. africana and $P$. stuhlmanni. Both of these taxa are important components in the diet of a number of zooplanktivorous fish in the St. Lucia Estuary (Blaber 1979). While Oikopleura spp. are the preferred food type for many fish species because of their high carbon and nitrogen content, as well as their lack of a carapace and slow reaction times (Gorsky \& Fenaux 1998), they also exhibit extremely fast generation rates (Deibel 1998). So, within the St. Lucia mouth, the effect of fish predation on $O$. dioica abundance may have been counterbalanced by their fast generation rates.

This community shift, however, lasted only for about 2 mo, as Oikopleura dioica disappeared completely from the estuary by the end of May 2008. A number of factors may have contributed to this. Firstly, the salinity dropped down to 23 ppt in May 2008, which, according to Uye \& Ichino (1995), is outside its range of tolerance. Secondly, in the absence of Pseudodiaptomus stuhlmanni and Mesopodopsis africana, O. dioica may have become the primary target of fish predation. Lastly, it has been shown that copepods in high abundance may have a significant impact on the abundance of appendicularians by ingesting their eggs and juveniles (López-Urrutia et al. 2004). Whichever combination of factors it may be, the zooplankton community at the mouth of the estuary, 2 mo subsequent to mouth reclosure, was dominated by Acartia natalensis, with an average individual size of about $800 \mu \mathrm{m}$. Only in October 2008 did the zooplankton community at the Mouth start resembling that of its pre-breaching state: large numbers of immature $M$. africana were once again recorded on this occasion, along with small populations of $P$. stuhlmanni.

Shifts in zooplankton community structure, especially the opportunistic dominance of Oikopleura dioica under closed-mouth conditions, emphasize the complexity and the erratic nature of the system in response to environmental variability. The unpredictable and extreme changes recorded in the present study concur with those reported by Grindley \& Heydorn (1970), where blooms of spiders, midges or dinoflagellates signalled major environmental change. The only major difference between the 2 studies was the types of organisms that flourished. In spite of severe environmental perturbations, the St. Lucia Estuary has been reported as being extremely resilient in the past (Begg 1978, Taylor 2006), but it is now critical to monitor the extent and the time scale of its recovery from the present drought-induced crisis, once a new wet cycle sets in.

Acknowledgements. Our sincere gratitude to the iSimangaliso Wetland Park Authority and the management and staff of Ezemvelo KZN Wildlife for their continuous support throughout this study. Special thanks to R. Taylor, C. Fox and A. Myeza. S. Haripurshad, G. Kruger and N. Miranda are gratefully acknowledged for their help in the field. Funding for this study was provided by the National Research Foundation (NRF), Marine and Coastal Management (MCM) and WWF.

\section{LITERATURE CITED}

Allanson BR, Read GHL (1995) Further comment on the response of Eastern Cape Province estuaries to variable freshwater flows. South Afr J Aquat Sci 21:56-70

Alldredge BR (1981) The impact of appendicularian grazing on natural food concentrations in situ. Limnol Oceanogr 26:247-257

Alldredge AL, Madin LP (1982) Pelagic tunicates: unique herbivores in the marine plankton. Bioscience 32:655-663

Beaugrand G (2005) Monitoring pelagic ecosystems from plankton indicators. ICES J Mar Sci 62:333-338

Begg GW (1978) The estuaries of Natal. Report no. 41, Natal Town and Regional Planning Commission, Pietermaritzburg, p 1-657

Benfield MC, Bosschieter JR, Forbes AT (1989) Growth and emigration of Penaeus indicus H. Milne-Edwards (Crustacea: Decapoda: Penaeidae) in the St. Lucia Estuary, Southern Africa. Fish Bull 88:21-28

Berner L (1967) Distributional atlas of Thaliacea in the California Current region. CalCOFI Atlas 8

Blaber SJM (1979) The biology of filter feeding teleosts in Lake St. Lucia, Zululand. J Fish Biol 15:37-59

Bonilla S, Conde D, Aubriot L, Pérez M (2005) Influence of hydrology on phytoplankton species composition and life strategies in a subtropical coastal lagoon periodically connected with the Atlantic Ocean. Estuaries 28:884-895

> Bonnet D, Frid CLJ (2004) Seven copepod species considered as indicators of water-mass influence and changes: results from a Northumberland coastal station. ICES J Mar Sci 61: $485-491$ 
Cyrus D, Vivier L (2006) Status of the estuarine fish fauna in the St. Lucia estuarine system, South Africa, after 30 months of mouth closure. Afr J Aquat Sci 31:71-81

Deibel DR (1980) Feeding, growth and swarm dynamics of neritic tunicates from the Georgia Bight. PhD thesis, University of Georgia, Athens, GA

Deibel D (1998) Feeding and metabolism of Appendicularia. In: Bone Q (ed) The biology of pelagic tunicates. Oxford University Press, Plymouth, p 139-150

Engel M (2005) Calanoid copepod resting eggs — a safeguard against adverse environmental conditions in the German Bight and the Kara Sea? Ber Polarforsch Meeresforsch 508:1-108

Fielding AT, Forbes AT, Demetriades NT (1991) Chlorophyll concentrations and suspended particulate loads in St. Lucia, a turbid estuary on the east coast of South Africa. Afr J Mar Sci 11:491-498

Fraser JH (1962) The role of ctenophores and salps in zooplankton production and standing crop. Rapp P-V Reun 153:121-123

Froneman PW (2004) Zooplankton community structure and biomass in a southern Africa temporarily open/closed estuary. Estuar Coast Shelf Sci 60:125-132

Gaughan DJ, Potter IC (1995) Composition, distribution and seasonal abundance of zooplankton in a shallow, seasonally closed estuary in temperate Australia. Estuar Coast Shelf Sci 41:117-135

Gleick P (2003) Global freshwater resources: soft-path solutions for the 21st century. Science 302:1524-1528

Gobler CJ, Cullison LA, Koch F, Harder TM, Krause JW (2005) Influence of freshwater flow, ocean exchange, and seasonal cycles on phytoplankton-nutrient dynamics in a temporarily open estuary. Estuar Coast Shelf Sci 65: $275-288$

Gorsky G, Fenaux R (1998) The role of Appendicularia in marine food webs. In: Bone Q (ed) the biology of pelagic tunicates. Oxford University Press, Plymouth, p 161-169

Grindley JR (1976) Zooplankton of St. Lucia. In: Heydorn AEF (ed) St. Lucia Scientific Advisory Council Workshop meeting, Charters Creek, 15-17 Feb 1976. Paper 12. Natal Parks Board, Pietermaritzburg

Grindley JR (1981) Estuarine plankton. In: Day JH (ed) Estuarine ecology with particular reference to southern Africa. AA Balkema, Rotterdam, p 117-146

Grindley JR (1982) The role of zooplankton in the St. Lucia estuary system. In: Taylor RH (ed) St. Lucia research review. Natal Parks Board, Pietermaritzburg

Grindley JR, Heydorn AEF (1970) Red water and associated phenomena in St. Lucia. S Afr J Sci 66:210-213

Hastie BF, Smith SDA (2006) Benthic macrofaunal communities in intermittent estuaries during a drought: comparisons with permanently open estuaries. J Exp Mar Biol Ecol 330:356-367

Hays GC, Richardson AJ, Robinson C (2005) Climate change and marine plankton. Trends Ecol Evol 20:337-344

Heip CHR, Goosen NK, Herman PMJ, Kromkamp J, Middelburg JJ, Soetaert K (1995) Production and consumption of biological particles in temperate tidal estuaries. Oceanogr Mar Biol Annu Rev 33:1-149

Heron AC (1972) Population ecology of a colonising species: the pelagic tunicate Thalia democratica I. Individual growth rates and generation time. Oecologia 10:269-293

Hopcroft RR, Roff JC (1995) Zooplankton growth rates: extraordinary production by the larvacean Oikopleura dioica in tropical waters. J Plankton Res 17:205-220

Jerling HL, Wooldridge TH (1995) Plankton distribution and abundance in the Sundays River Estuary, South Africa, with comments on potential feeding interactions. S Afr J Mar Sci 15:169-184

Kibirige I, Perissinotto R (2003) The zooplankton community of the Mpenjati Estuary, a South African temporarily open/closed system. Estuar Coast Shelf Sci 58:727-741

Kibirige I, Perissinotto R, Thwala X (2006) A comparative study of zooplankton dynamics in two subtropical temporarily open/closed estuaries, South Africa. Mar Biol 148: $1307-1324$

Kiørboe T, Nielsen TG (1994) Regulation of zooplankton biomass and production in a temperate, coastal ecosystem. 1. Copepods. Limnol Oceanogr 39:493-507

López-Urrutia A, Harris RP, Smith T (2004) Predation by calanoid copepods on the appendicularian Oikopleura dioica. Limnol Oceanogr 49:303-307

> McEwen GF, Johnson MW, Folsom TR (1954) A statistical analysis of the performance of the Folsom plankton splitter based on test observations. Meteorol Atmos Phys 7: 502-527

> Mirza MMQ (2003) Climate change and extreme weather events: can developing countries adapt? Clim Policy 3: $233-248$

Moore M, Folt CL, Stemberger RS (1996) Consequences of elevated temperatures for zooplankton assemblages in temperate lakes. Arch Hydrobiol 135:289-319

Norberg J, DeAngelis D (1997) Temperature effects on stocks and stability of a phytoplankton-zooplankton model and the dependence on light and nutrients. Ecol Model 95: 75-86

Nozais C, Perissinotto R, Mundree S (2001) Annual cycle of microalgal biomass in a South African temporarily open estuary: nutrient versus light limitation. Mar Ecol Prog Ser 223:39-48

> Perissinotto R, Wooldridge TH (1989) Short-term thermal effects of a power-generating plant on zooplankton in the Swartkops Estuary, South Africa. PSZN I: Mar Ecol 10: 205-219

Perissinotto R, Walker DR, Webb P, Wooldridge TH, Bally R (2000) Relationships between zoo- and phytoplankton in a warm-temperate, semi-permanently closed estuary, South Africa. Estuar Coast Shelf Sci 51:1-11

Perissinotto R, Blair A, Connell A, Demetriades NT and others (2004) Contribution to information required for the implementation of Resource Directed Measures for estuaries, Vol 2. Responses of the biological communities to flow variation and mouth state in two KwaZulu-Natal temporarily open/closed estuaries. Water Research Commission, Pretoria, Report No. 1247/2/04

Pillay D, Perissinotto R (2008) The benthic macrofauna of the St. Lucia Estuary during the 2005 drought year. Estuar Coast Shelf Sci 77:35-46

Pillay D, Perissinotto R (2009) Community structure of epibenthic meiofauna in the St. Lucia Estuarine Lake during a drought cycle. Estuar Coast Shelf Sci 81:94-104

> Primo AL, Azeiteiro UM, Marques SC, Martinho F, Pardal MÂ (2009) Changes in zooplankton diversity and distribution pattern under varying precipitation regimes in a southern temperate estuary. Estuar Coast Shelf Sci 82:341-347

Ranasinghe R, Pattiaratchi C (2003) The seasonal closure of tidal inlets: causes and effects. Coast Eng 45:601-627

> Roemmich D, McGowan J (1995) Climatic warming and the decline of zooplankton in the California Current. Science 267:1324-1326

> Roy PS, Williams RJ, Jones AR, Yassini I and others (2001) Structure and function of south-east Australian estuaries. Estuar Coast Shelf Sci 53:351-384

Taylor R (2006) Ecological responses to changes in the physi- 
cal environment of the St. Lucia estuary, South Africa. PhD thesis, Norwegian University of Life Sciences, Ås

Taylor R, Kelbe B, Haldorsen S, Botha GA, Wejden B, Vaeret L, Simonsen MB (2005) Groundwater-dependent ecology on the shoreline of the subtropical Lake St Lucia estuary. Environ Geol 49:586-600

Uye S (1985) Resting egg production as a life-history strategy of marine planktonic copepods. Bull Mar Sci 37:440-449

Uye S, Ichino S (1995) Seasonal variation in abundance, size composition, biomass and production rate of Oikopleura dioica (Fol) (Tunicata: Appendicularia) in a temperate eutrophic inlet. J Exp Mar Biol Ecol 189:1-11

Whitfield AK (1980) A quantitative study of the trophic relationships within the fish community of the Mhlanga Estuary. Estuar Coast Mar Sci 10:417-435

Whitfield AK (1992) A characterisation of southern African

Editorial responsibility: Otto Kinne,

Oldendorf/Luhe, Germany estuarine systems. S Afr J Aquat Sci 18:89-103

Whitfield AK, Taylor RH (2009) A review of the importance of freshwater inflow to the future conservation of Lake St Lucia. Aquatic Conserv: Mar Freshw Ecosyst 19:838-848

Willams-Howze J (1997) Dormancy in the free-living copepod orders Cyclopoida, Calanoida, and Harpacticoida. Oceanogr Mar Biol 35:257-321

Wooldridge TH (1986) Distribution, population dynamics and estimates of production for the estuarine mysid, Rhopalophthalmus terranatalis. Estuar Coast Shelf Sci 23:205-223

Wooldridge TH (1999) Estuarine zooplankton community structure and dynamics. In: Allanson BR, Baird D (eds) Estuaries of South Africa. Cambridge University Press, Cambridge, p 141-166

Zar JH (1996) Biostatistical analysis, 4th edn. Prentice Hall, Upper Saddle River, NJ

Submitted: June 2, 2009; Accepted: October 5, 2009

Proofs received from author(s): January 18, 2010 